\title{
Experimental horizontal transmission of viral hemorrhagic septicemia virus (VHSV) in Japanese flounder Paralichthys olivaceus
}

\author{
K. Muroga ${ }^{1,4, *}$, H. Iida1 ${ }^{1}$ K. Mori ${ }^{2}$, T. Nishizawa ${ }^{3}$, M. Arimoto ${ }^{2}$ \\ ${ }^{1}$ Graduate School of Biosphere Sciences, Hiroshima University, Higashihiroshima 739-8528, Japan \\ ${ }^{2}$ The Kamiura Station, Japan Sea-Farming Association, Kamiuracho, Oita 879-2602, Japan \\ ${ }^{3}$ Graduate School of Fisheries Sciences, Hokkaido University, Hakodate 041-8611, Japan \\ ${ }^{4}$ Present address: Graduate School of Agricultural Science, Tohoku University, Sendai 981-8555, Japan
}

\begin{abstract}
Infection by viral hemorrhagic septicemia virus (VHSV) has recently occurred among wild and farmed Japanese flounder Paralichthys olivaceus in Japan. In the present study, horizontal transmission of VHSV among Japanese flounder was experimentally demonstrated by immersion challenge. Exposure to a flounder isolate (Obama25) of VHSV revealed a dose-response, with higher mortality (81 and $70 \%$ ) at the 2 higher exposure levels $\left(6.0\right.$ and $\left.4.0 \log _{10} \mathrm{TCID}_{50} \mathrm{ml}^{-1}\right)$. In a second experiment, high titers of VHSV were expressed from moribund and dead flounder based on virus detection in holding-tank waters 2 to $3 \mathrm{~d}$ prior to death of the fish and $1 \mathrm{~d}$ after death. The virus could not be detected in tank waters $2 \mathrm{~d}$ after death. Finally, a third cohabitation experiment in small tanks demonstrated horizontal transmission of VHSV from experimentally infected to uninfected fish.
\end{abstract}

KEY WORDS: Viral hemorrhagic septicemia virus · Paralichthys olivaceus · Horizontal transmission · Immersion challenge $\cdot$ Waterborne route

\section{INTRODUCTION}

Viral hemorrhagic septicemia (VHS) is a serious viral disease of farmed rainbow trout Oncorhynchus mykiss, primarily in European countries (Wolf 1988). It is listed as a notifiable disease by the Office International des Epizooties (2003: see www.oie.int/eng/normes/ fmanual). Near the end of the 1980s, the causative virus, VHSV, was first reported from various marine fishes in Europe (Schlotfeldt et al. 1991, Mortensen et al. 1999) and in anadromous salmon (Winton et al. 1989) and marine fishes of North America (Meyers \& Winton 1995, Meyers et al. 1999). The virus seems to be ubiquitous among marine fishes (Dixon 1999, Smail 1999, Winton \& Einer-Jensen 2002).

From 1999 to 2001, the first reports of VHSV in Asia occurred, with isolations from wild Japanese flounder Paralichthys olivaceus collected from several coastal areas of Japan (Takano et al. 2000, 2001, Watanabe et al. 2002). In 1996, a new viral disease was observed in cultured Japanese flounder in the Inland Sea of Japan, and subsequently the causative agent was identified as VHSV (Isshiki et al. 2001). Because Japanese flounder is one of the most important farmed fish species in Japan, various studies of the disease and virus have been conducted, including studies on the histopathology of affected flounder (Isshiki et al. 2001), on the genotype of flounder VHSV isolates (Nishizawa et al. 2002), on the physiological and pathological properties of VHSV (Isshiki et al. 2002, Mori et al. 2002), and on the susceptibility of VHSV to various disinfectants (Kurita et al. 2002). In a previous immersion exposure study examining the fate of VHSV in flounder, we showed that the highest virus titers $\left(\sim 10 \log _{10} \mathrm{TCID}_{50} \mathrm{~g}^{-1}\right)$ occurred in the heart, kidney and spleen (Iida et al. 2003).

Detection trials of VHSV from spawners, eggs and larvae of the Japanese flounder have been conducted in some hatcheries, but the virus has not yet been iso- 
lated. In grow-out facilities, horizontal transmission appears to be essential for the spread of the virus among cultured flounder populations and from wild to cultured fish. In the present study, the occurrence of horizontal transmission of VHSV among Japanese flounder was demonstrated experimentally.

\section{MATERIALS AND METHODS}

Virus. The Obama25 strain of VHSV (Genogroup I) from wild Japanese flounder (Takano et al. 2000) was thawed from $-80^{\circ} \mathrm{C}$ for titer determination. All virus titrations and assays were performed in 96-well plates (inoculation dose: $50 \mu \mathrm{l}$ ) with a fathead minnow (FHM) cell line, using Eagle's minimal essential medium supplemented with $10 \%$ fetal bovine serum $\left(\mathrm{MEM}_{10}\right)$ at $20^{\circ} \mathrm{C}$ for $14 \mathrm{~d}$ (Mori et al. 2002).

Fish. Japanese flounder derived from VHSV-negative spawners and reared in ozonated seawater at $20^{\circ} \mathrm{C}$ in the hatchery at the Kamiura Station of the Japan Sea-Farming Association were used after $1 \mathrm{wk}$ acclimation at $13^{\circ} \mathrm{C}$. During the acclimation period, 10 fish were randomly tested for virus on FHM cells using samples of the brain, head kidney and spleen.

Immersion challenge experiment (Expt 1). We immersed 3 groups of Japanese flounder (25 to 27 fish per group, average body weight $59 \mathrm{~g}$ ) in ozonated seawater at $13^{\circ} \mathrm{C}$ for $1 \mathrm{~h}$. The seawater contained VHSV at $2.0,4.0$ or $6.0 \log _{10} \mathrm{TCID}_{50} \mathrm{ml}^{-1}$. A control group (25 fish) was immersed in $10^{-3}$-diluted $\mathrm{MEM}_{10}$ for $1 \mathrm{~h}$. After challenge, each group was placed in a $50 \mathrm{l}$ tank with flow-through (1 turnover $\mathrm{h}^{-1}$ ) ozonated seawater at $13^{\circ} \mathrm{C}$. All fish were fed a pelleted commercial diet at a rate of $1 \%$ whole body weight $\mathrm{d}^{-1}$ and monitored for mortality until 21 to $24 \mathrm{~d}$ post-infection (d.p.i.), i.e. until no mortality had occurred for 5 consecutive days. Necropsy of dead fish included sampling the brain, head kidney, heart and spleen; these were then stored at $-80^{\circ} \mathrm{C}$ for subsequent virus isolation. After termination of the experiment, surviving fish were examined for the virus, except for the 10 surviving fish at the lowest dose $\left(2.0 \log _{10} \mathrm{TCID}_{50} \mathrm{ml}^{-1}\right)$.

Measurement of virus expression in tank water (Expt 2). We challenged 10 flounder (average body weight $18 \mathrm{~g}$ ) by immersion in $5.6 \log _{10} \mathrm{TCID}_{50} \mathrm{ml}^{-1}$ of VHSV for $1 \mathrm{~h}$ at $13^{\circ} \mathrm{C}$. After challenge, each fish was placed into a separate $5 \mathrm{l}$ tank of non-flowing ozonated seawater (water volume $1 \mathrm{l}$ ) at $13^{\circ} \mathrm{C}$ and monitored for $14 \mathrm{~d}$ with aeration and no feeding. In each tank, water samples of $\sim 5 \mathrm{ml}$ were taken by a pipette for titration of VHSV and bacterial counts every $24 \mathrm{~h}$, and the water was changed. Filtered $(0.45 \mu \mathrm{m})$ and serially $10^{-1}$-diluted seawater samples ( $50 \mu \mathrm{l}$ of each dilution in duplicate) were inoculated onto FHM cells in 96-well plates, and bacterial counts were made every other day by incubating non-filtered seawater samples (100 $\mu$ l of each dilution in duplicate) in Marine Agar (Difco) at $25^{\circ} \mathrm{C}$ for 2 d. For controls, 2 uninfected fish were immersed in $10^{-3}$-diluted $\mathrm{MEM}_{10}$ for $1 \mathrm{~h}$ and similarly monitored for viral titers and bacterial counts in tank waters.

The microbial monitoring continued in each tank for $14 \mathrm{~d}$, and 1 surviving virus-exposed fish and 2 control fish were tested for virus at the termination of the experiment.

Cohabitation experiment (Expt 3). A cohabitation experiment was conducted with flounder (average body weight $15 \mathrm{~g}$ ) by first challenging 20 fish (donor fish) by immersion in $5.6 \log _{10}$ TCID $_{50} \mathrm{~m}^{-1}$ of virus for $1 \mathrm{~h}$ at $13^{\circ} \mathrm{C}$. We placed 10 of the donor fish in a $20 \mathrm{l}$ tank (Tank A) with a net partition, and the remaining 10 fish in another $20 \mathrm{l}$ tank (Tank B) with no partition. The same number of uninfected fish (recipient fish) with fin-cut marks were introduced into Tank B and into the opposite side of the partition of Tank A to avoid direct contact with the donor fish. A third tank (C) contained 10 fish that had been previously immersed in $\mathrm{MEM}_{10}$ and 10 uninfected fish with no partition as a negative control group.

Fish in all tanks were reared for 4 wk in flowing seawater with aeration, and were fed a commercial diet. When a donor fish died, it was removed $1 \mathrm{~d}$ after death to titrate virus from its brain, head kidney and heart. When a recipient fish died, it was immediately sampled for viral titration.

\section{RESULTS}

\section{Immersion challenge (Expt 1)}

VHSV was not isolated from any fish examined during the acclimation period. A dose-response with high mortality ( 81 and $70 \%$ ) occurred in the 2 fish groups exposed to the highest concentrations of VHSV (6.0 and $4.0 \log _{10}$ $\mathrm{TCID}_{50} \mathrm{ml}^{-1}$, respectively) (Fig. 1). In the fish group challenged with the lowest concentration of VHSV $\left(2.0 \log _{10}\right.$ TCID $_{50} \mathrm{ml}^{-1}$ ), only 4 fish died $(16 \%)$, but the virus was recovered from $82 \%$ of the surviving fish examined (Table 1). High virus titers were detected in the heart, head kidney and spleen of dead fish at $\sim 7$ to $8 \log _{10}$ $\mathrm{TCID}_{50} \mathrm{~g}^{-1}$ regardless of virus concentrations. Most moribund fish in all challenge groups displayed extensive hemorrhages of the skin, fins, body muscle and viscera.

\section{Virus expression in tank water (Expt 2)}

The titration results of VHSV in tank water containing individual virus-infected flounder (V1 to V10) or 


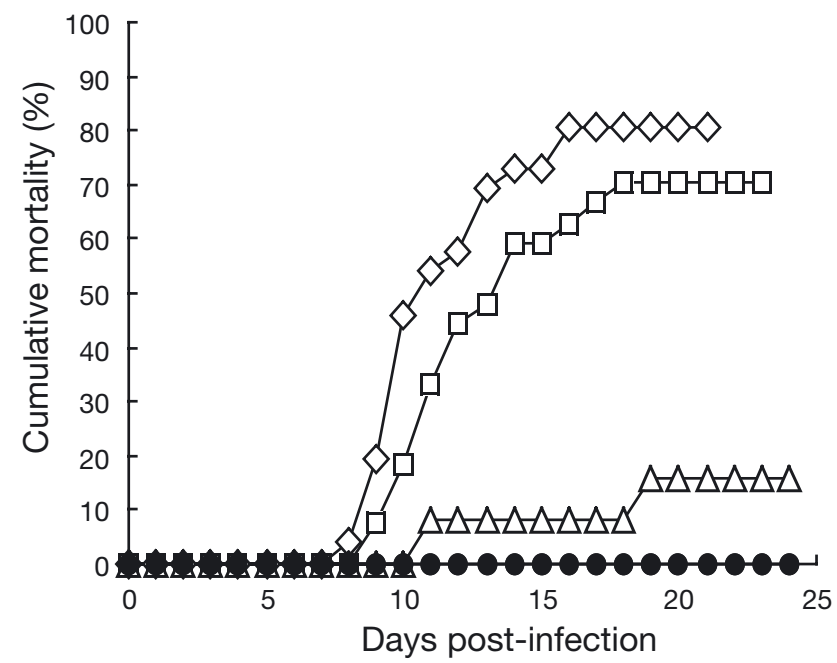

Fig. 1. Paralichthys olivaceus. Cumulative mortality of Japanese flounder challenged by immersion with flounder isolate Obama25 of viral hemorrhagic septicemia virus (VHSV) at 3 different concentrations for $1 \mathrm{~h}$ at $13^{\circ} \mathrm{C}$ (Expt 1$)$. $(\diamond, \square, \Delta): 6.0,4.0$ and $2.0 \log _{10} \mathrm{TCID}_{50} \mathrm{ml}^{-1}$, respectively;

(•) $\mathrm{MEM}_{10}$ (control)

Table 1. Paralichthys olivaceus. Recovery of VHSV (Obama25) from dead and surviving flounder challenged by immersion (Expt 1)

\begin{tabular}{|c|c|c|c|}
\hline \multirow{2}{*}{$\begin{array}{l}\text { Challenge conc. } \\
\left(\log _{10} \mathrm{TCID}_{50} \mathrm{ml}^{-1}\right)\end{array}$} & \multirow[t]{2}{*}{$\begin{array}{c}\text { Mortality (\%) } \\
\text { (dead/total) }\end{array}$} & \multicolumn{2}{|c|}{$\begin{array}{l}\text { Re-isolation rate }(\%) \\
\quad \text { (positive/tested) }\end{array}$} \\
\hline & & Dead & Surviving \\
\hline 6.0 & $81(21 / 26)$ & $100(21 / 21)$ & $100(5 / 5)$ \\
\hline 4.0 & $70(19 / 27)$ & $95(18 / 19)$ & $100(8 / 8)$ \\
\hline 2.0 & $16(4 / 25)$ & $100(4 / 4)$ & $82(9 / 11)$ \\
\hline Control $\left(\mathrm{MEM}_{10}\right)$ & $0(0 / 25)$ & 0 & $0(0 / 25)$ \\
\hline
\end{tabular}

control fish $(\mathrm{C} 1, \mathrm{C} 2)$ are given in Table 2. VHSV was detected in the seawater of all tanks containing infected fish. Most fish (90\%) died between 5 and 9 d.p.i., and the virus was detected from 1-4 d prior to death to 1-2 d after death (Table 2). Viral titers in the water of tanks containing moribund or dead fish were 2.3 to $4.6 \log _{10} \mathrm{TCID}_{50} \mathrm{ml}^{-1}$, with an average of $3.5 \log _{10} \mathrm{TCID}_{50} \mathrm{ml}^{-1}$. The virus was not detected on the first day in 1 tank, on the second day in 6 tanks, or on the third day in 2 tanks after fish mortality.

Changes in the bacterial counts of water in 10 experimental tanks and in 2 tanks containing negative control fish are shown in Table 3. Bacterial numbers were stable at about $10^{4}$ to $10^{5} \mathrm{CFU}$ (colony forming units) $\mathrm{ml}^{-1}$ in the 2 control tanks and the test tank (V10) in which the fish did not die, and in the other 9 test tanks before fish mortality. The CFU rapidly increased to $10^{6}-10^{7} \mathrm{CFU} \mathrm{ml} \mathrm{m}^{-1}$ after fish mortality in the 9 test tanks.

VHSV was isolated from 1 surviving challenged fish (V10), but not from the 2 control fish at the termination of the experiment.

\section{Cohabitation (Expt 3)}

In the cohabitation experiment, mortality of donor fish began on Day 7 of cohabitation (= 7 d.p.i.) in both Tanks A and B, and cumulative mortality of the donors reached $80 \%$ (Tank A) and 100\% (Tank B) (Fig. 2). In recipient fish, mortality began on Day 11 and reached $50 \%$ (Tank A) and $40 \%$ (Tank B). VHSV was detected in all dead fish and surviving recipient fish, except for 1 fish in Tank A.

Table 2. VHSV $\left(\log _{10} \mathrm{TCID}_{50} \mathrm{ml}^{-1}\right)$ in tank water containing individual VHSV (Obama25)-infected Paralichthys olivaceus (V1 to V10) and negative control fish $(\mathrm{C} 1, \mathrm{C} 2)$. d.p.i.: days post-infection; <: below detection limit $\left(1.8 \log _{10} \mathrm{TCID}_{50} \mathrm{ml}^{-1}\right)$; : days on which fish displayed morbidity and clinical signs of infection; $\quad$ : days on which fish died

\begin{tabular}{|c|c|c|c|c|c|c|c|c|c|c|c|c|}
\hline \multirow{2}{*}{ d.p.i. } & \multicolumn{2}{|c|}{ Control } & \multirow[b]{2}{*}{ V1 } & \multirow[b]{2}{*}{$\mathrm{V} 2$} & \multirow[b]{2}{*}{ V3 } & \multirow[b]{2}{*}{$\mathrm{V} 4$} & \multicolumn{2}{|c|}{ VHSV-challenged } & \multirow[b]{2}{*}{ V7 } & \multirow[b]{2}{*}{ V8 } & \multirow[b]{2}{*}{ V9 } & \multirow[b]{2}{*}{ V10 } \\
\hline & $\mathrm{C} 1$ & $\mathrm{C} 2$ & & & & & V5 & V6 & & & & \\
\hline 0 & $<$ & $<$ & $<$ & $<$ & $<$ & $<$ & $<$ & $<$ & $<$ & $<$ & $<$ & $<$ \\
\hline 1 & $<$ & $<$ & $<$ & $<$ & $<$ & $<$ & $<$ & $<$ & $<$ & $<$ & $<$ & $<$ \\
\hline 2 & $<$ & $<$ & $<$ & $<$ & $<$ & $<$ & $<$ & $<$ & $<$ & $<$ & $<$ & $<$ \\
\hline 3 & $<$ & $<$ & $<$ & $<$ & $<$ & $<$ & $<$ & 2.1 & 2.6 & $<$ & $<$ & $<$ \\
\hline 4 & $<$ & $<$ & $<$ & $<$ & $<$ & $<$ & $<$ & 2.8 & 3.6 & $<$ & $<$ & $<$ \\
\hline 5 & $<$ & $<$ & $<$ & $<$ & $<$ & $<$ & $<$ & 3.1 & 4.3 & 3.1 & 2.8 & $<$ \\
\hline 6 & $<$ & $<$ & 2.8 & $<$ & $<$ & 2.3 & 3.1 & 3.6 & 3.1 & $<$ & 3.1 & $<$ \\
\hline 7 & $<$ & $<$ & 2.6 & 2.3 & 4.1 & 3.1 & 2.6 & 4.3 & $<$ & 3.6 & 2.3 & $<$ \\
\hline 8 & $<$ & $<$ & 3.3 & $<$ & 4.1 & 3.1 & $<$ & $<$ & $<$ & 4.1 & 4.6 & $<$ \\
\hline 9 & $<$ & $<$ & 3.1 & 2.8 & 2.6 & 2.1 & $<$ & $<$ & $<$ & 2.3 & 4.1 & $<$ \\
\hline 10 & $<$ & $<$ & $<$ & 5.1 & $<$ & 2.1 & $<$ & $<$ & $<$ & $<$ & 2.6 & 2.1 \\
\hline 11 & $<$ & $<$ & $<$ & 3.6 & $<$ & $<$ & $<$ & $<$ & $<$ & $<$ & $<$ & $<$ \\
\hline 12 & $<$ & $<$ & $<$ & $<$ & $<$ & $<$ & $<$ & $<$ & $<$ & $<$ & $<$ & $<$ \\
\hline 13 & $<$ & $<$ & $<$ & $<$ & $<$ & $<$ & $<$ & $<$ & $<$ & $<$ & $<$ & $<$ \\
\hline 14 & $<$ & $<$ & $<$ & $<$ & $<$ & $<$ & $<$ & $<$ & $<$ & $<$ & $<$ & $<$ \\
\hline
\end{tabular}


Table 3. Bacterial counts $\left(\log _{10} \mathrm{CFU} \mathrm{ml}{ }^{-1}\right)$ in tank water containing individual VHSV (Obama25)-infected Paralichthys olivaceus (V1 to V10) and negative control fish (C1, C2). d.p.i.: days post-infection. [ : days after fish mortality

\begin{tabular}{|c|c|c|c|c|c|c|c|c|c|c|c|c|}
\hline \multirow{2}{*}{ d.p.i. } & \multicolumn{2}{|c|}{ Control } & \multirow[b]{2}{*}{ V1 } & \multirow[b]{2}{*}{$\mathrm{V} 2$} & \multirow[b]{2}{*}{ V3 } & \multirow[b]{2}{*}{ V4 } & \multicolumn{2}{|c|}{ VHSV-challenged } & \multirow[b]{2}{*}{ V7 } & \multirow[b]{2}{*}{ V8 } & \multirow[b]{2}{*}{ V9 } & \multirow[b]{2}{*}{ V10 } \\
\hline & $\mathrm{C} 1$ & $\mathrm{C} 2$ & & & & & V5 & V6 & & & & \\
\hline 1 & 3.7 & 3.5 & 3.9 & 3.8 & 3.8 & 3.9 & 4.0 & 4.2 & 3.7 & 3.6 & 3.8 & 4.0 \\
\hline 3 & 4.5 & 4.3 & 4.7 & 4.5 & 4.6 & 4.6 & 4.4 & 4.6 & 4.7 & 4.8 & 4.5 & 4.3 \\
\hline 5 & 4.3 & 4.5 & 4.6 & 4.7 & 4.6 & 5.0 & 5.2 & 4.9 & 5.1 & 4.9 & 4.8 & 4.6 \\
\hline 7 & 4.6 & 4.6 & 4.8 & 4.6 & 4.8 & 5.1 & 4.8 & 6.7 & 7.2 & 5.0 & 4.8 & 4.8 \\
\hline 9 & 4.3 & 4.6 & 6.4 & 4.5 & 6.8 & 5.9 & 7.1 & 6.7 & 7.4 & 6.7 & 5.1 & 5.1 \\
\hline 11 & 4.6 & 4.6 & 6.7 & 6.1 & 7.4 & 6.9 & 7.2 & 7.4 & 6.4 & 7.4 & 6.9 & 5.5 \\
\hline 13 & 4.5 & 4.6 & 7.1 & 7.3 & 6.9 & 7.1 & 7.2 & 7.8 & 7.3 & 7.6 & 7.0 & 5.6 \\
\hline
\end{tabular}

\section{DISCUSSION}

Our immersion challenge tests (Expt 1) confirmed that Japanese flounder is highly susceptible to the flounder isolate Obama25 of VHSV, showing a clear dose-response, with high infection rates and decreasing mortality at the lowest exposure concentration (2.0 $\log _{10} \mathrm{TCID}_{50} \mathrm{ml}^{-1}$ ). Wolf (1988) reported that a standardized immersion challenge in juvenile rainbow trout weighing 0.5 to $5 \mathrm{~g}$ requires $5 \times 10^{4} \mathrm{PFUs}$ (plaque forming units) $\mathrm{ml}^{-1}$ Egtved virus (VHSV Genogroup III, Stone et al. 1997) for $3 \mathrm{~h}$. The flounder isolates of VHSV, including the present isolate Obama25, belong to Genogroup I (Nishizawa et al. 2002), and a representative isolate has been confirmed to be non-virulent to rainbow trout (K. Nakajima et al. unpubl.) as have American isolates of Genogroup I (Stone et al. 1997). The susceptibility of Japanese flounder to Genogroup I VHSV appears to be higher than that of rainbow trout to Genogroup III isolates.

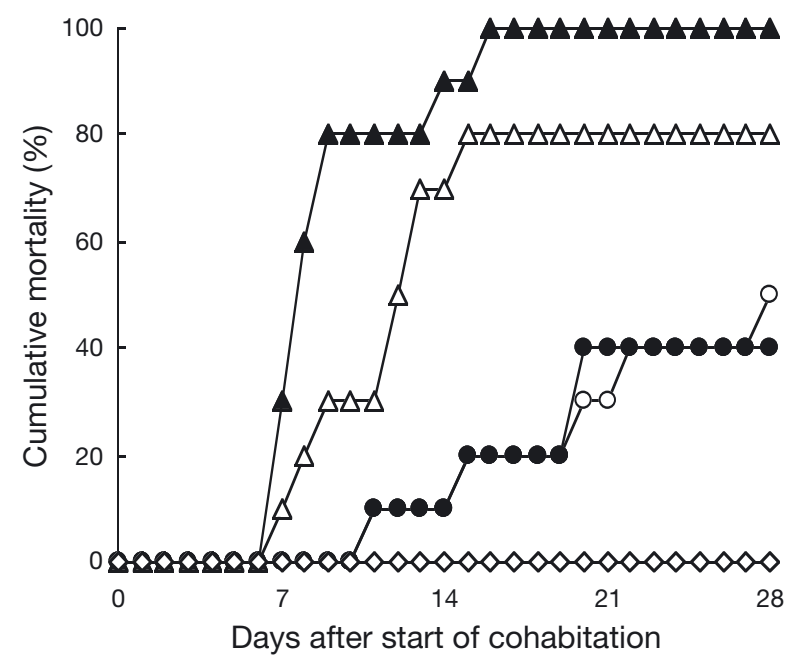

Fig. 2. Paralichthys olivaceus. Cumulative mortality in cohabitation experiment (Expt 3) with VHSV (Obama25)-infected (donor) and uninfected (recipient) fish at $13^{\circ} \mathrm{C}$. Recipient $(\mathrm{O})$ and donors $(\Delta)$ in net-partitioned tank (Tank A); recipient $(\bullet)$ and donors $(\mathbf{\Lambda})$ in the non-partitioned tank (Tank B); recipient and donors $(\diamond)$ in negative control tank
Among the marine fishes collected from coastal areas of Japan, VHSV has been isolated almost exclusively from Japanese flounder, although it has also been detected in Japanese sand lance Ammodytes personatus (Watanabe et al. 2002). This indicates that the Japanese flounder is the major host of VHSV in this area. However, it may not be a long-standing host of VHSV, since its susceptibility to the virus is very high, and VHS has occurred only recently in this fish despite its long culture history.

The present study (Expt 2) has clearly demonstrated that VHSV is expressed by experimentally infected moribund or dead flounder in high concentrations, with an average titer of $3.5 \log _{10} \mathrm{TCID}_{50} \mathrm{ml}^{-1}$ in holding-tank water. The average total virus expressed in moribund/dead fish was calculated as $6.8 \log _{10} \mathrm{TCID}_{50}$ fish $^{-1} \mathrm{~d}^{-1}$ or $3.4 \log _{10} \mathrm{TCID}_{50} \mathrm{fish}^{-1}$ $\mathrm{h}^{-1}$. This is slightly lower than the $10^{6.5} \mathrm{PFU} \mathrm{fish}^{-1} \mathrm{~h}^{-1}$ reported for Pacific herring Clupea pallasi (Kocan et al. 1997), but far higher than the minimal infective dose $\left(2.0 \log _{10} \mathrm{TCID}_{50} \mathrm{ml}^{-1}\right)$ in our immersion experiment, indicating that horizontal transmission of VHSV in ambient seawater can occur among Japanese flounder reared in tanks. Infected fish showing abnormalities should thus be removed from tanks as soon as possible, i.e. before they can express large amounts of VHSV.

The virus could not be detected in tank waters ca. $2 \mathrm{~d}$ after the death of fish. Its disappearance is primarily due to cessation of virus multiplication after death of the host fish, but may also partly be due to the increased number of bacteria in a tank following fish mortality (Table 3). A similar result showing that survival of the virus in seawater is affected by the presence of bacteria was shown in a previous in vitro experiment, whereby VHSV infectivity was much reduced in non-autoclaved seawater compared with that in autoclaved seawater (Mori et al. 2002). However, more work is necessary to determine whether bacterial abundance is responsible for viral inactivation, since no factors other than bacterial abundance were examined in the present study. 
Horizontal transmission of VHSV among infected and uninfected flounder was demonstrated by our cohabitation experiment (Expt 3), as already reported for the turbot Scophthalmus maximus (Snow \& Smail 1999). Contrary to expectations, direct contact between fish did not influence the mortality of the recipient fish: there was no difference in mortality of recipient fish between contact and non-contact groups of flounder. This could have been due to the high amounts of expressed virus present in the tank in this experiment.

\section{LITERATURE CITED}

Dixon PF (1999) VHSV came from the marine environment: clues from the literature, or just red herrings? Bull Eur Assoc Fish Pathol 19:60-65

Iida H, Mori K, Nishizawa T, Arimoto M, Muroga K (2003) Fate of viral hemorrhagic septicemia virus in Japanese flounder Paralichthys olivaceus challenged by immersion. Fish Pathol 38:87-91 (in Japanese with English abstract)

Isshiki T, Nishizawa T, Kobayashi T, Nagano T, Miyazaki T (2001) An outbreak of VHSV (viral hemorrhagic septicemia virus) infection in farmed Japanese flounder Paralichthys olivaceus in Japan. Dis Aquat Org 47:87-99

Isshiki T, Nagano T, Miyazaki T (2002) Effect of water temperature on pathological states of Japanese flounder experimentally infected with viral hemorrhagic septicemia virus, a flounder isolate KRRV-9601. Fish Pathol 37:95-97

Kocan R, Bradley M, Elder N, Meyers T, Batts W, Winton J (1997) North American strain of viral hemorrhagic septicemia virus is highly pathogenic for laboratory-reared Pacific herring. J Aquat Anim Health 9:278-290

Kurita J, Iida Y, Nakajima K, Inouye K (2002) Virucidal effects of various disinfectants on viral hemorrhagic septicemia virus (VHSV) isolated from Japanese flounder. Fish Pathol 37:175-181 (in Japanese with English abstract)

Meyers TR, Winton JR (1995) Viral hemorrhagic septicemia virus in North America. Annu Rev Fish Dis 5:3-24

Meyers TR, Short S, Lipton K (1999) Isolation of the North American strain of viral hemorrhagic septicemia virus (VHSV) associated with epizootic mortality in 2 new host species of Alaskan marine fish. Dis Aquat Org 38:81-86

Mori K, Iida H, Nishizawa T, Arimoto M, Nakajima K, Muroga K (2002) Properties of viral hemorrhagic septicemia virus (VHSV) isolated from Japanese flounder Paralichthys

Editorial responsibility: Jo-Ann Leong, Kaneohe, Hawaii, USA olivaceus. Fish Pathol 37:169-174

Mortensen HF, Heuer OE, Lorenzen N, Otte L, Olesen NJ (1999) Isolation of viral haemorrhagic septicaemia virus (VHSV) from wild marine fish species in the Baltic Sea, Kattegat, Skagerrak and the North Sea. Virus Res 63: 95-106

Nishizawa $T$, Iida $H$, Takano $R$, Isshiki $T$, Nakajima $K$, Muroga K (2002) Genetic relatedness among Japanese, American and European isolates of viral hemorrhagic septicemia virus (VHSV) based on partial G and P genes. Dis Aquat Org 48:143-148

Schlotfeldt HJ, Ahne W, Vestergard-Jorgensen PE, Glende W (1991) Occurrence of viral haemorrhagic septicaemia in turbot (Scophthalmus maximus). A natural outbreak. Bull Eur Assoc Fish Pathol 11:105-107

Smail D (1999) Viral haemorrhagic septicaemia. In: Woo PTK, Bruno DW (eds) Fish diseases and disorders, Vol 3. CABI Publishing, New York, p 123-147

Snow M, Smail DA (1999) Experimental susceptibility of turbot Scophthalmus maximus to viral haemorrhagic septicaemia virus isolated from cultivated turbot. Dis Aquat Org 38:163-168

Stone DM, Way K, Dixon PF (1997) Nucleotide sequence of the glycoprotein gene of viral haemorrhagic septicaemia (VHS) viruses from different geographical areas: a link between VHS in farmed fish species and viruses isolated from North Sea cod (Gadus morhua L.). J Gen Virol 78: 1319-1326

Takano R, Nishizawa T, Arimoto M, Muroga K (2000) Isolation of viral haemorrhagic septicaemia virus (VHSV) from wild Japanese flounder, Paralichthys olivaceus. Bull Eur Assoc Fish Pathol 20:186-193

Takano R, Mori K, Nishizawa T, Arimoto M, Muroga K (2001) Isolation of viruses from wild Japanese flounder Paralichthys olivaceus. Fish Pathol 36:153-160

Watanabe L, Pakingking R Jr, Iida H, Nishizawa T, Iida Y, Arimoto M, Muroga K (2002) Isolation of aquabirnavirus and viral hemorrhagic septicemia virus (VHSV) from wild marine fishes. Fish Pathol 37:189-191

Winton, JR, Einer-Jensen K (2002) Molecular diagnosis of infectious hematopoietic necrosis and viral hemorrhagic septicemia. In: Cunningham CO (ed) Molecular diagnosis of salmonid diseases. Kluwer, Dordrecht, p 49-79

Winton JR, Batts WN, Nishizawa T, Stehr CM (1989) Characterization of the first North American isolates of viral hemorrhagic septicemia virus. Newsl Am Fish Soc, Fish Health Sec $17: 2-3$

Wolf K (1988) Fish viruses and fish viral diseases. Cornell University Press, Ithaca, NY

Submitted: April 10, 2003; Accepted: October 21, 2003

Proofs received from author(s): February 23, 2004 